UDC 349.2

DOI https://doi.org/10.32841/2307-1745.2019.41-2.10

Lagutina I. V.,

Doctor of Legal Sciences,

Head of the Department of Labour Law and Social Security Law of National University "Odessa Law Academy"

\title{
PART-TIME WORK AS ATYPICAL WORK
}

Summary. The article emphasizes that the use of part-time work temporary employment leads to increased inequality and insecurity that undermines prospects for economic development, causing a steady decline in the living standards of employees. This article analyzes the problem of legislative regulation of relations between employers and employees. It is important to note that employers who are responsive to the desires and needs of their employees not only have more satisfied staff, but also benefit from their higher degree of motivation in carrying out their work. Improved motivation leads to higher productivity and a higher standard of work, which ultimately benefit the business.

Part-time work is one type of non-standard employment that undoubtedly has grown since the onset of the recession. It has grown for decades due to the structural shift in the economy towards services and preferences for part-time work, not least related to the increase in female labour force participation.

Younger employees, less educated employees and - especially - employees new to their current job or those on temporary employment contracts are more likely to be involuntary part-time employees. Lower-paid service occupations, elementary occupations and sales and service workers account the majority of all involuntary part-time employment.

In respect of employment conditions, part-time employees shall not be treated in a less favourable manner than comparable full-time employees solely because they work part time unless different treatment is justified on objective grounds.

There are a lot of reasons working part time might make sense: among them, you have more hours in the week to take care of kids or parents, take on freelance work, go back to school. But working part time can stall career advancement, and oftentimes women end up doing a full-time job for half the pay while taking on more responsibilities at home.

Key words: decent work, personal non-property labour rights, employee, part-time work, inequality.

Problem setting. Labour law is one of the fastest moving areas in the law today. However, the role of the classic employment relationship is undergoing major rethinking at the current time and part-time work becomes more widespread in both developed and developing countries. The use of such form of employment leads to increased inequality and insecurity that undermines prospects for economic development, causing a steady decline in the living standards of employees.

Analysis of recent researches and publications. Topical issues of legal regulation of such kind of non-standard forms of employment as part-time work in a market economy is the subject of study of Ukrainian and foreign scientists, such as: F. Andersson, A.P. Bizyukov, A.K. Bhandari, I. Brinkley, P.H. Cappelli, S. Clauwaert, P. Fadeuilhe, C. Gather, E.S. Gerasimova, V.E. Gimpelson, S.Y. Golovina, M. Hall, T. Hartmann, A. Heshmati,
R.I. Kapelyushnikov, J.R. Keller, I.J. Kiselev, T.Y. Korshunova, M. Kurzina, I.A. Kostyan, C. Lang, I. Motorna, A. Muller, A.F. Nurtdinova, A.S. Prylypko, A.P. Rymkevich, J. Thompson, S.A. Saurin, I. Schömann, G. Vakhitova, H. Wilson, S. Wölfing, G. Wünsche, I.I. Zavodovsky, O. Yaroshenko etc.

The purpose of this article is to examine the main characteristics of temporary employment, to research issues of ensuring the individual and collective labour rights of part-time employees.

Article's main body. Non-standard forms of employment contracts cover diverse forms of employment relationships. The most common forms are fixed-term contracts and part-time contracts that are particularly affected by the impact of the economic crisis, putting employees in a very insecure and precarious position. Part-time contracts were used for their flexibility compared to standard contracts, existing regulations on fixed-term and part-time work were adapted and loosened to facilitate recourse to more flexible forms of work contracts, and even more flexible forms of employment were introduced by creating new types of contract.

According to ILO Convention № 175 on Part-Time Work (1994) the term part-time worker means an employed person whose normal hours of work are less than those of comparable full-time workers; the normal hours of work referred to in subparagraph (a) may be calculated weekly or on average over a given period of employment; the term comparable full-time worker refers to a full-time worker who: a) has the same type of employment relationship; b) is engaged in the same or a similar type of work or occupation; and c) is employed in the same establishment or, when there is no comparable full-time worker in that establishment, in the same enterprise or, when there is no comparable full-time worker in that enterprise, in the same branch of activity, as the parttime worker concerned.

According to the Framework Agreement on part-time work implemented by Council Directive 97/81/EC [1], the equal treatment of part-time workers refers to the prohibition of discrimination against those.

Whose normal hours of work, calculated on a weekly basis or on average over a period of employment of up to one year, are less than the normal hours of work of a comparable full-time worker.

Nonetheless, under EU law, less favourable treatment of parttime workers is justifiable provided the treatment is on grounds unrelated to sex discrimination. A court must strike a balance between the discriminatory effect of the condition of less favourable treatment and the reasonable needs of the party who applies the condition. Moreover, the business needs of an employer may outweigh the rights of a part-time worker to equal treatment. However, if discrimination is established against female part-time workers, their maximum entitlement under EU law is to equal 
treatment with male full-time workers on a pro-rata basis, though this may not resolve the many challenges posed by part-time work.

Part-time work itself comes in many varieties, from very short weekly working hours to levels comparable with full-time work (up to and over 30 hours per week is one conventional cut-off for determining part-time weekly working hours).

Looking at fixed-term employment in relation to the economic situation reveals its conflicting nature. While employees on a fixedterm contract are easier to dismiss during an economic recession, fixed-term employment can help to increase employment during an economic boom.

Temporary work is booming, in particular in Germany. Almost two percent of all employees are temps rented by agencies to other companies to meet peaks in demand without hiring new staff. The politicians who came up with the idea originally believed that the system would allow the German economy to better react to business fluctuations. At the same time, temporary work would help unemployed people get into permanent jobs. That's how it works in theory, anyway [2]. But in practice, several companies recognized the tremendous saving potential that came with hiring cheap temporary workers instead of sticking to their more expensive permanent employees.

The German government is taking steps to attract stay-at-home mothers into the labour market and to encourage those with parttime jobs to work more (currently, 69\% of all working mothers are part-timers). In September, it published the Gute-Kita (Good Kindergarten) Act, which makes provision for childcare subsidies for lower-income families. It also addresses the quality of childcare and includes measures to improve the qualifications of carers and to increase the opening hours of day-care centres. The government will invest $€ 5.5$ billion up to 2020 in the programme.

Part-time work is carried out for many different reasons, reflecting the interest of workers, employers, or both. When looking at the advantages and disadvantages of part-time work, it is important to distinguish between voluntary and involuntary part-time, taking into account the 'hidden' involuntary part-timers trapped in this form of work due to lack of other options. Research shows that parttime work has a series of different consequences for employees, employers and the economy as a whole. For example, part-time work is understood to increase female participation in the labour force, and therefore has a positive effect on the employment rate. It allows employers to adjust their resources to cyclical conditions over the course of a day/week/month/year and it also allows businesses to respond to the economic cycle. For employees it may be a solution to maintaining their work-life balance, enabling parents to spend more time with their children while remaining in employment. At the same time, part-time work may increase overall labour costs for businesses due to the presence of fixed costs. Employees working part-time have lower earnings and fewer possibilities, on average, for career progression. Some results suggest that the quality of parttime jobs is on average lower, although the job satisfaction of parttime workers is, on the whole, similar to that of full-time workers.

It should be noted that, precarious work is frequently associated with, but cannot be considered identical to the following types of employment: "part-time employment, self-employment, fixed-term work, temporary work, on-call work, home working, and telecommuting." All of these forms of employment are related in that they depart from the standard employment relationship (fulltime, continuous work with one employer), but they are not in all cases to be considered precarious, since a good legislation and/or good collective agreements can secure these contract forms [3].

Discrimination against part-time workers refers to unfair or unequal treatment of those whose normal working week agreed under the contract of employment is shorter than that of full-time employees.

Nevertheless, views are divided on the issue of non-standard forms of employment.

The Report for discussion at the Meeting of Experts on NonStandard Forms of Employment (Geneva, 16-19 February 2015) sets out a typology of non-standard employment, and presents a general overview of the prevalence and growth of different forms of non-standard employment around the world, the reason for its use, and its effects on workers, firms and the labour market, with special attention paid to fundamental principles and rights at work. It also reviews ILO standards, regional and national regulation of the different types of non-standard employment, and recent reforms.

Work under non-standard forms of employment contracts can affect employees in a variety of ways. Empirical evidence suggests that de facto earnings of workers in non-standard forms of employment may differ from those of regular workers. Workers employed under non-standard forms of employment contracts frequently have inadequate employment-based social security coverage, either because they are explicitly excluded from receiving coverage by law or because their short tenure, short contribution periods or low earnings may limit access to such entitlements. Although they are faced with many of the same risks as other workers, because multiple parties are involved, with the contracting agency paying the wages but the user firm giving the instructions, there is greater potential for accidents, even if responsibility for safety and health at the workplace lies with the user firm. Workers in non-standard forms of employment may experience difficulty in joining trade unions or in being covered by collective bargaining agreements [4].

Non-standard forms of employment contacts are being widely used also in Ukraine.

Part-time employment (defined statistically as employees who work fewer than 35 hours per week) is the most widespread type of non-standard employment found among women. Broader public policies aimed at women in non-standard work can either reinforce gender stereotyping - and its subsequent ramifications in the labour market - or remedy it. Indeed, differences in labour force participation rates frequently reflect prevailing social welfare policies, tax policies and the provision of public services. In this regard, it is important to institute policies aimed at increasing overall labour force participation of women by promoting tax systems that favour second earners, and making it easier for women and men to reach better work-family balance through publicly funded and adequate care services, public transfers, and suitable and quality workplace working time [5].

The multivariate analysis reinforces some of the findings of the descriptive analysis, but falsifies some of the others. It confirms that being of temporary status, working in lower-level service occupations (sales and service workers and, especially, elementary occupations) or similar sectors (households as employers) as well as having only started one's current job within the last year are all factors associated with a higher prevalence of involuntary part-time work. Conversely, being of long tenure 
or working in a predominantly male-employing sector such as manufacturing (also utilities and construction) is associated with a lower prevalence of involuntary part-time work. While having a graduate-level education provides a (modest) level of protection against involuntary part-time status compared with those who completed secondary education in the full model (where all employees is the population), this effect becomes insignificant in the part-time only model.

Conclusions. This makes it impossible the spread for these workers a legal mechanism for ensuring labour rights, including personal non-property labour rights.

Better work-life balance has an implicit societal value that is linked to gender equality and quality of life. It also has an economic dimension, with poor work-life balance hampering participation in the labour market. It has been proven that more attractive working arrangements have the potential to boost labour supply for those who find it difficult to reconcile rigid working arrangements with their family commitments [6, p. 9].

Ukraine should ratify ILO Convention № 175 on Part-Time Work 1994. Particularly, measures shall be taken to ensure that part-time workers receive the same protection as that accorded to comparable full-time workers in respect of: the right to organize, the right to bargain collectively and the right to act as workers' representatives; occupational safety and health; discrimination in employment and occupation.

With the purpose of resolving the situation in the labour market, it is necessary to introduce an efficient strategy for creating jobs, directed at increasing employment and the effective protection of individuals from unemployment, to improve legal mechanisms to encourage employers to create new productive high-tech workplaces [7, p. 449].

This is especially true that part-time employees must receive the same treatment as full-time permanent staff. Specifically, it is important to ensure that temporary employees enjoy equality and non-discrimination in terms of wages, social benefits, training, and access to collective bargaining.

Social dialogue can play a relevant role. The Law of Ukraine "On Social Dialogue in Ukraine" determines the legal principles of organizing and the procedure for holding social dialogue in Ukraine with the purpose of developing and implementing the state social and economic policy, regulating labour, social and economic relations, and ensuring improvement of the living standard and the quality of life, as well as social stability in the society. Article 8 of the Law envisages that social dialogue is conducted between the parties of social dialogue in the following forms: exchange of information; consultation; reconciliatory procedures; collective negotiations on conclusion of collective agreements.

Ukrainian legislation should include a provision stating that the employees have the same individual and collective labour rights as other categories of employees, including personal non-property labour rights.

\section{References:}

1. Council Directive $97 / 81 /$ EC of 15 December 1997 concerning the Framework Agreement on part-time work concluded by UNICE, CEEP and the ETUC. URL: https://eur-lex.europa.eu/legal-content/ EN/TXT/?uri=CELEX:31997L0081

2. Hurley J. Estimating labour market slack in the European Union. Publications Office of the European Union, Luxembourg. 2017. 56 p.
3. Wolfgang D. Temp labor: modern slaves, or economic heroes? 2013 URL: http://www.dw.com/en/temp-labor-modern-slaves-or-economic-heroes/a-16656289.

4. What is precarious work? URL: http://www.precariouswork.eu.

5. Non-standard forms of employment. Report for discussion at the Meeting of Experts on Non-Standard Forms of Employment (Geneva, 16-19 February 2015). International Labour Office, Conditions of Work and Equality Department, Geneva, 2015.

6. Blau F., Kahn L. Female labor supply: Why is the US falling behind? IZA Discussion Paper No. 7140 (Bonn, Institute for the Study of Labor). 2013.

7. Work-life balance and flexible working arrangements in the European Union / Eurofound, Dublin, 2017. 23 p.

8. Щорічна доповідь Уповноваженого Верховної Ради України 3 прав людини про стан дотримання прав і свобод людини і громадянина в Україні. Київ, 2016. 538 с.

Лагутіна I. В. Неповний робочий час як один із видів нестандартної зайнятості

Анотація. У статті підкреслюється, що використання тимчасової зайнятості на умовах неповного робочого часу призводить до збільшення нерівності та невпевненості, що підриває перспективи економічного розвитку, спричиняючи стійке зниження життєвого рівня працівників. У цій статті проаналізовано проблему законодавчого регулювання відносин між роботодавцями та працівниками. Важливо зауважити, що роботодавці, які реагують на бажання та потреби своїх працівників, не тільки мають більш задоволений персонал, але й отримують перевагу від свого вищого ступеня мотивації у виконанні своєї роботи. Поліпшена мотивація призводить до підвищення продуктивності праці та більш високого рівня праці, що в кінцевому рахунку принесе користь бізнесу.

Неповний робочий час - це один із видів нестандартної зайнятості, який, безсумнівно, зростав 3 моменту наступу рецесії. Він зростає протягом десятиліть завдяки структурному переходу економіки до послуг та переваги встановлення неповного робочого часу, що не в останню чергу пов'язане зі збільшенням участі жінок у робочій силі.

Молоді працівники, менш освічені працівники та особливо працівники, 3 якими укладені строкові трудові договори, швидше за все будуть вимушеними працівниками, для яких встановлено неповний робочий час. Низькооплачувані професії, елементарні професії та працівники сфери продажів і обслуговування складають більшість усіх примусових неповних робочих місць.

Що ж до умов зайнятості, то до працівників із неповним робочим часом не слід ставитися менш сприятливо, ніж до працівників, які працюють повний робочий день, лише тому, що вони працюють неповний робочий день, якщо інше поводження не виправдане з об'єктивних причин.

Є багато причин, коли робота за встановленого неповного робочого часу може мати сенс: серед них наявність часу, щоб піклуватися про дітей чи батьків, брати участь у позаштатній роботі, повертатися до школи. Але цей вид робочого часу може зупинити просування в кар'єрі, і часто жінки в кінцевому підсумку роблять повний робочий день за половину зарплати, беручи на себе більше обов'язків вдома.

Ключові слова: гідна робота, особисті немайнові трудові права, працівник, неповний робочий час, нерівність. 